\title{
LESSON STUDY IMPLEMENTASI STRATEGI PEMBELAJARAN "CEGERA" BERBASIS PRODUK MENGGUNAKAN METODE THINK PAIR SHARE
}

\author{
Okto Wijayanti \\ Universitas Muhammadiyah Purwokerto, Purwokerto, Indonesia \\ wijayantiokto@ump.ac.id
}

\begin{abstract}
This study aims to determine the implementation of the "Cegera" learning strategy based on dance products (song movements) in the 6th semester of FKIP UMP student art courses. The study population was 6 students. The method used in this study was carried out in 3 stages, namely plan, do, and see. Data collection techniques used were interview method, observation method, and documentation method. The data analysis used is descriptive qualitative. The results of this study are (1) The implementation of the "Cegera" learning strategy consists of 3 steps, namely the implementation of storytelling strategies, expression and song movements. (2) make students active, cooperate with each other, and responsibility in the learning process. (3) The process of implementing learning strategies is emphasized with pleasant, fun and relaxed conditions so as to enable students to freely express ideas, concepts, exchange opinions, think together, explore and explore. (3) The dance product produced through the implementation of "Ceg" learning was successfully presented in the final semester practice exam. The Quick Strategy Findings can be recommended for dance-based practice courses.
\end{abstract}

Keywords: Cegera, Think Pair Share, Lesson Study

\begin{abstract}
Abstrak. Penelitian ini bertujuan untuk mengetahui implementasi strategi pembelajaran "Cegera" berbasis Produk karya tari (gerak lagu) pada matakuliah kesenian mahasiswa semester 6 FKIP UMP. Populasi penelitian berjumlah 6 mahasiswa. Metode yang digunakan dalam penelitian ini dilaksanakan dengan 3 tahap yaitu plan, do, dan see. Teknik pengumpulan data yang digunakan yaitu metode wawancara, metode observasi, dan metode dokumentasi. Analisis data yang digunakan adalah deskriptif kualitatif. Hasil dari penelitian ini adalah (1) Implementasi strategi pembelajaran "Cegera" terdiri dari 3 langkah yakni implementasi strategi bercerita, berekspresi dan gerak lagu. (2) membuat siswa aktif, saling bekerja sama, dan tanggung jawab dalam proses pembelajaran. (3) Proses implementasi strategi pembelajaran ditekankan dengan syarat menyenangkan, asyik dan santai sehingga memungkinkan mahasiswa bebas mengemukakan ide, konsep, bertukar pendapat, berfikir bersama, bereksplorasi dan bereksplorasi. (3) Produk karya tari yang dihasilkan memalui implementasi pembelajaran "Cegera" berhasil dipresentasikan dengan baik dalam ujian praktek akhir semester. Temuan Strategi Cegera dapat direkomendasikan unuk mata kuliah praktek berbasis karya tari.
\end{abstract}

Kata Kunci : Cegera, Lesson Study, Think Pair Share

\section{PENDAHULUAN}

Pemberlakuan Kurikulum 2013 berimplikasi pada perlunya pengembangan pembelajaran. Baik calon guru SD, sebelum melaksanakan kegiatan pembelajaran perlu mempersiapkan diri. Salah satu bentuk persiapan adalah menyusun model pembelajaran yang sesuai dengan karakteristik perkembangan fisik dan psikologis anak usia dini, keadaan lingkungan sekitar dan ketersediaan sarana dan prasarana. Dari berbagai pembelajaran yang perlu disusun oleh guru, diantaranya adalah pembelajaran bidang pengembangan kemampuan seni. Kemampuan seni merupakan salah satu dari bidang kemampuan dasar yang 
dikembangkan untuk meningkatkan kreativitas anak yang bermuara ke arah pembentukan karakter.

Pembelajaran Seni adalah sejumlah kegiatan yang dapat dilakukan oleh anak dengan lebih banyak melibatkan kemampuan motorik, khususnya motorik halus. Pembelajaran seni yang membuat anak tertarik yaitu dengan mengenalkan gerak dan lagu. Pada kenyataannya, masih sedikitnya pembelajaran gerak dan lagu yang diterapkan kepada anak usia dini oleh pendidik, yang mengakibatkan anak tidak senang bermain alat musik, kurang senang bernyanyi sambil menari, merasa sulit menghafal lagu, dan kurang peka terhadap suara-suara musik.

Penelitian ini mengkaji bagaimana implementasi mahasiswa calon guru PGPAUD dalam menerapkan strategi pembelajaran "Cegera" di kelas Kesenian (Seni Tari) dalam menghasilkan produk tari kreasi (gerak lagu) dmelalui strategi Think Pair Share. Masih sedikitnya pembelajaran gerak dan lagu yang diterapkan kepada anak usia dini oleh pendidik, yang mengakibatkan anak tidak senang bermain alat musik, tidak senang bernyanyi, merasa sulit menghafal lagu, bernyanyi dan kurang peka terhadap suara-suara. Masih banyak anak yang merasa malu dan takut ketika ibu gurunya meminta untuk bernyanyi dan bergerak sesuai lagu, padahal dengan musik dan nyanyian dapat menyalurkan, mengendalikan, menimbulkan rasa senang, lucu, haru dan kagum. Hal ini sangat erat kaitannya dengan perkembangan psikomotorik anak

Penerapan strategi pembelajaran "Cegera" adalah strategi pembelajaran dengan menggabungkan kegiatan bercerita, berekspresi dan gerak lagu yang akan diterapkan pada mahasiswa
PGPAUD, selanjutnya mahasiswa tersebut mengajarkan proyek berupa karya tari pada anak usia dini. Strategi "Cegera" ini adalah strategi baru yang inovatif ini menarik sekali untuk diteliti dan dikaji lebih dalam bagaimana kegiatan perencanaannya, pelaksanaannya dan evaluasi sampai pada penampilan proyek karya tari oleh mahasiswa PGPAUD. Strategi Pembelajaran "Cegera" ini diasumsikan dapat memberikan manfaat yang positif pada mahasiswa PGPAUD nantinya dapat melaksanakan pembelajaran ini dan khusus nya untuk anak usia dini sebagai anak didiknya sehingga mahaiswa calon guru PAUD bisa memilih strategi yang menyenangkan dan menarik dalam menghasilkan produk karya tari (gerak lagu) sesuai dengan perkembangan kognitif, afektif dan psikomotorik anak usia dini. Upaya peningkatan sikap kerjasama salah satunya dapat dilaksanakan menggunakan model pembelajaran Kooperatif tipe Think Pai Share.

Pembelajaran Kooperatif tipe Think Pair Share memiliki prosedur yang ditetapkan secara eksplisit untuk memberi siswa waktu lebih banyak untuk berfikir, menjawab, dan saling membantu satu sama lain. Pertama kali dikembangkan oleh Frang Lyman dan koleganya di Universitas Maryland sesuai yang dikutip Kurniasih Imas dan Berlin Sani (2015: 58), menyatakan bahwa Think-Pair-Share merupakan cara yang efektif untuk membuat variasi suasana pola diskusi kelas

\section{METODE PENELITIAN}

Penelitian ini menggunakan metode kualitatif berbasis Lesson study, pendekatan ini digunakan sebagai prosedur penelitian yang menghasilkan deskripsi berupa kata-kata tertulis atau 
lisan dari orang-orang dan perilaku yang dapat diamati. Penggunaan metode penelitian ini disesuaikan dengan tujuan pokok penelitian yaitu mengkaji bagaimana implementasi strategi pembelajaran Cegera berbasis proyek karya tari dan drama pada mata kuliah kesenian.

Populasi penelitian berjumlah 8 orang mahasiswa Semester 4 PGPAUD. Penetapan fokus penelitian merupakan tahap yang sangat menentukan dalam penelitian kualitatif. Hal tersebut karena suatu penelitian kualitatif tidak dimulai dari sesuatu yang kosong atau tanpa adanya masalah (Moleong 2007:92). Jadi fokus dalam penelitian kualitatif pada dasarnya adalah sumber pokok dari masalah penelitian (Moleong 2007:386). Sesuai dengan judul penelitian, maka sasaran atau fokus pada penelitian ini mengacu pada rumusan masalah, yaitu mengkaji implementasi strategi pembelajaran, proses pembelajaran melalui metode Think Pair Share dan bentuk produk karya tari setelah strategi pembelajaran "Cegera" dimplementasikan. Selanjutnya Rancangan penelitian selama 1 semester adalah sebagai berikut.

\section{Rancangan Penelitian}

\section{1). Tahap Perencanaan}

Kegiatan yang dilaksanakan pada tahap ini adalah sebagai beikut ;

(a) Menyusun kompetensi dasar dan tujuan pembelajaran pada tiap pertemuan,

(b) Menyiapkan tes performance awal untuk mengetahui sejauh mana kemampuan, kepercayaan diri dan keberanian mahasiswa,

(c) Menyiapkan instrumen penelitian.

(d) Menyiapkan Lembar observasi aktivitas belajar kelompok.

2). Tahap Pelaksanaan (a). Membagi kelas menjadi 4 pasang (8 mahasiswa)

(b). Memberikan tes performance awal

(c). Membagikan kompetensi dasar dan tujuan pembelajaran

(d). Menerapkan strategi pembelajaran Cegera, metode Kooperatif, Think Pair Share, motivasi, penguatan dan simpulan konsep dasar.

(e). Presentasi, Evaluasi

(f). Melaksanakan tes performance akhir.

3) Tahap Observasi dan Evaluasi Tindakan

(a). Mengobservasi proses pembelajaran

(b). Mengevaluasi performance proyek karya gerak lagu.

(c). Menilai proyek hasil kinerja

\section{Metode Pengumpulan Data}

Pengumpulan data dalam penelitian kualitatif dapat dilakukan dengan beberapa macam teknik pengumpulan data. Penelitian ini menggunakan tiga teknik pengumpulan data. Teknik pengumpulan data yang digunakan yaitu metode wawancara, metode observasi, dan metode dokumentasi.

\section{a. Observasi}

Observasi adalah tindakan atau proses pengambilan informasi melalui media pengamatan (Sukardi 2006: 49). Dalam hal ini peneliti melakukan pengamatan, pencatatan secara sistematik terhadap kejadian-kejadian, objek-objek yang dilihat dan hal-hal lain yang diperlukan dalam mendukung penelitian yang sedang dilakukan. Dalam penelitian ini observasi dilakukan secara terus terang yaitu menyatakan terus terang kepada sumber data (informan) bahwa peneliti melakukan pengamatan. Data yang diambil oleh peneliti meliputi proses pembelajaran. Pelaksanaan strategi Cegera, Think Pair Share, dan bentuk 
kerjasama, serta pemberian bimbingan atau bantuan kepada mahasiswa selama pembelajaran, perencanaan, pelaksanaan, evaluasi, koreksi proyek karya tari.

b. Wawancara

Pengumpulan data melalui teknik wawancara dilakukan kepada informan utama dan informan pendukung. Wawancara dilakukan pada mahasiswa PGPAUD FKIP UMP dan anak usia dini (TK) yang nantinya akan melihat hasil proyek tari karya mahasiswa PGPAUD melalui strategi "Cegera." Serta kendala yag terjadi.. Wawancara dilakukan dalam bentuk wawancara terstruktur dan wawancara mendalam (deptinterview).

\section{c. Studi dokumen}

Penggunaan studi dokumen adalah untuk mendukung dan menambah bukti dari sumber-sumber lain. Teknik studi dokumen dilakukan dengan mengkaji dokumen guru berupa video hasil karya, foto, silabus, RPP, dan RKH.

\section{HASIL DAN PEMBAHASAN}

Setiap mahasiswa membuat sebuah cerita berdasarkan pada pemilihan musik tari yang sudah dipilih dalam kelompok. Setiap mahasiswa menentukan tema dengan isi cerita yang dikembangkan sendiri. Setiap mahasiswa dipanggil secara acak untuk mempresentasikan hasil ceritanya kepada mahasiswa lain, dengan durasi waktu maksimal 7 menit saja (cerita singkat dan menarik). Kegiatan bercerita dibuat asyik, tidak tegang, santai dan menyenangkan. Mahasiswa penutur melakukan tanya jawab (umpan balik) secara santai dan menyenangkan kepada mahasiswa lain (pendengar). Gerakan tangan dan ekspresi mimik muka sangat ditekankan dalam strategi bercerita.

\section{Langkah-langkah Strategi Cegera dan Think Pair Share sebagai berikut.}

a. Mahasiswa harus memahami ide cerita, tema cerita yang disampaikan.

b. Mahasiswa menyampaikan hasil temuannya kepada pasangannya mempresentasikan ekspresi yang terdapat dalam alur atau isi cerita dengan maju di depan kaca

c. Mahasiswa mempresentasikan ekspresi gerak di depan kaca lalu mencatat ekspresi yang ditemukan.

Langkah-Lngkah menyusun gerak lagu sebagai berikut.

a. Mahasiswa bereksplorasi secara individu kemudian mencatat temuan geraknya dari awal sampai akhir.

b. Mahasiswa mempresentasikan temuan gerak secra individu lalu menyampaikan kepada pasangannya

c. Mahasiswa berpasangan berdiskusi menyusun gerak. Lalu menggabungkan ide dalam satu kelompok setelah berdiskusi.

d. Tiap kelompok mempresentasikan produk tari (gerak dan lagunya) diiringi musik beserta koreografinya.

e. Mahasiswa berdiskusi dengan dosen mengenai make up dan kostumnya

f. Evaluasi proses pembuatan karya diakhiri dengan penilaian ujian praktek

\section{Pelaksananaan Pembelajaran}

Tahapan pelaksanaan pembelajaran dibagi menjadi 3 tahap meliputi : 1) Implementasi kegiatan Bercerita, 2) bereskpresi dan 3). Presentasi gerak lagu diakhiri dengan penilaian ujian praktek akhir semester, sehingga implementasi strategi Pembelajaran "Cegera" ini membutuhkan waktu 1 semester.

Garis besar kegiatan pembelajaran selama 1 semester sebagai berikut. a. Implementasi strategi pembelajaran 


\begin{abstract}
Mahasiswa bercerita kepada mahasiswa lain, dilanjutkan Implementasi strategi ekspresi dengan cara mengekspresikan gerak dan mimik muka di depan kaca. Implementasi strategi pembelajaran gerak lagu, yakni mahasiswa bereskplorasi membuat kreasi gerakan yang sesuai dengan tema, dan alur cerita yang sampaikan dengan menerapkan ekspresi gerak dan ekspresi mimik wajahnya. Dalam pelaksanaan kegiatan ini diperoleh 2 judul gerak lagu yakni ; "Kembali ke Sekolah" dan "Rame-Rame". Durasi tari (gerak lagu) sekitar 5 menit. Musik ini adalah musik lagu nyanyian anakanak yang dibuat kreasi gerak oleh mahasiswa PGPAUD. Gerak dipresentasikan secara berkelompok yang dibuat sederhana, menarik, lincah dan gembira sesuai dengan tema dari tariannya. Mahasiswa mempresentasikan gerak lagu dengan menari sambil bernyanyi.
\end{abstract}

Kegiatan dalam Think, mahasiswa mulai memiliki motivasi untuk berpikir dan menemukan ide untuk mewujudkan proyek karya tarinya. Fenomena yang terjadi dalam kehiatan Think adalah keinginan mahasiswa untuk menunjukkan kemampuannya, dn mengumpulkan keinginan, rancangan, draft serta ide-ide yang sungguh luar biasa yang ingin disampikan kepada pasangannya. Memang sudah diatur bahwa dalam pemilihan pasangan tidak secara acak, namun telah dirancang bahwa mahasiswa yang kurang dipasangkan dengan mahasiswa yang setingkat lebih baik kemampuan awalnya, sehingga memang dapat diamati bahwa terjadi sikap kerjasama dalam berpasangan. Kegiatan share, mahasiswa yang aktif dan dinilai mampu tadi menshare segala ide, draf, angan-angan, keinginan yang telah dicatat dalam sebuah catatan temuan kepada pasangannya. Think Pair share yang berhasil dilaksanakan dalam pembelajaran selama 1 semester terbukti dapat meningkatkan kerjasama mahasiswa. Hasil pegamatan dalam proses pembelajaran menggunakan strategi Cegera menggunakan strategi Think Pair Share memunculkan sikap saling menghargai. Rasa saling memiliki bahwa mereka adalah satu tim perlu arahkan secara terus menerus. Pada akhirnya sejalan dengan terlaksananya kerjasama dalam satu tim dalam menghasilkan proyek karya tari melalui proses yang panjang.

Proses pelaksanaan pembelajaran sama sekali tidak terdapat kendala karena syarat strategi pembelajaran "Cegera" yang asyik, menyenangkan dan santai dapat diterapkan dengan baik. Implementasi strategi pembelajaran "Cegera" efektif diterapkan karena membuat mahasiswa lebih bebas berkomunikasi sesama anggota kelompoknya (pemilihan anggota kelompok didasarkan pada atas dasar saling cocok dan kenal) sehingga kebebasan bereksplorasi dan mengekspresikan ide garapannya sehingga kreatifitas produk atau karya tari (gerak lagu) dipresentasikan dengan baik. Produk karya tari (gerak dan lagu dapat lebih baik lagi apabila kepercayaan diri ketika menari dapat lebih dimaksimalkan lagi.

\section{SIMPULAN}

Implementasi strategi pembelajaran "Cegera berbasis Produk ini secara langsung dapat meningkatkan karakter bekerja sama dengan kelompok, toleransi, menghagai. Pembelajaran praktek khususnya seni tari atau keterampilan tari, diperlukan latihan di luar jam pelajaran sehingga 
tanggungjawab individu dan kekompkan tim dapat dinilai dari hasil karya (produk gerak dan lagunya). Kreatifitas dan kesiapan karya gerak lagu tidak akan maksimal apabila mahasiswa tidak memiliki sikap dan karaktek kerjasama. Temuan Strategi Cegera dapat direkomendasikan unuk mata kuliah praktek berbasis karya tari.

\section{DAFTAR PUSTAKA}

Delphie, Bandi. Program Pembelajaran Individual Berbasis Gerak Irama. Bandung : Pustaka Bani Quraisy.

Dhieni. 2006. Metode Pengembangan Bahasa. Jakarta : Universitas Terbuka.

Hamdani. 2010. Strategi Belajar Mengajar. Bandung : Pustaka Setia.

Fizal, Rizaldi. 2008. Pengertian Bahasa Lisan : artikel. Vol I. No 2.(http/organisasi.Oran/Definisi. Pengertian Bahasa Lisan.com/ Diakss 24 Maret 2016.

Miles B Mathew \& A. Michael Huberan. 1996. Analisi Data Kualitatif. Terjemahan Ceecep Rohendi. Jakarta : UI. Press.

Mulyani, Novi.2016. Pendidikan Anak Usia Dini. Yogyakarta : Gava Media.
Mustakim, Nur. 2001. Metode Pengembangan Bahasa. Jakarta : Universitas Terbuka.

Moleong, Lexy. 2002. Metodologi Penelitian Kualitatif. Bandung: PT. Remaja Rosda Karya.

Ni'mah, Khafidhotan. Penerapan Metode Diskusi Berbantuan Media Gambar sebagai Upaya Peningkatan Minat Belajar Siswa dalam Pembelajaran IPS di SMP Negeri 1 Karangmoncol Kabupaten Purbalingga. Skrispsi. Yogyakarta: UNY.

Undang-Undang Sistem Pendidikan Nasional Tahun 2003.

Widodo. 2008. Perkembangan Bicara dan bahasa ; Perembangan Bahasa anak Pra Sekolah (on line). Vol 1. No. 3 9http/www.childenclinic.com./D iakses 22 Maret 2016.

Sudjana. 2004. Manajemen Program Pendidikan. Bandung.

Sukardi.2006. Penelitian Kualitatif Naturalisttik dalam Pendidikan. Usaha Keluarga : Yogyakarta.

Yunaryo, Ardian. 2012. Implementasi Kurikulum Tingkat Satuan Pendidikan Di Sekolah Dasar Masjid Syuhada' Yogyakarta. Skripsi. UNY. 